Instruments of labor (technologies) not only supply a standard of the degree of development which human labor has attained, but they are also indicators of the social conditions under which that labor is carried on. - Karl Marx ${ }^{1}$

Evaluating the socio-technical dialectic reveals much about our values as a society, as a construction industry and as individual disciplines. This paper will share an interpretive cultural history of building in order to establish a context for the emergence of integrated practice technologies such as BIM, IPD and LEED. This will provide the foundation for determining whether these technologies are serving us well in contemporary practice given our most pressing challenges and opportunities. In short the purpose of this paper is to explain the context of building as a means for making our current practices more performative, that is less abstract and autonomous, and instead more connected, meaningful and valuable to the future of both society and the building industry.

\section{HISTORY OF FRAGMENTATION}

Building on Vitruvian principles, the Renais- sance marked two distinct thought systems in building. The first is most clearly exemplified by Brunelleschi and his team who in the mid1400 's was commissioned to finish the dome to the Cathedral in Florence, Italy. The Duomo is based on human proportions integrating structure, function and form, and as with many works of the Renaissance, is associated with a singular name, although many surely helped in the endeavor. Brunelleschi's team acted as designer, engineer, contractor, subcontractor, material scientist, and supplier. These Renaissance builders invented a new type of hoist to lift the large stones for the dome of the cathedral. This holistic approach to building is a prime example of master builder integration. (Fig.1)

The second thought system on building in the Renaissance is represented in the example of Alberti, a contemporary of Brunelleschi, who in contrast to master builders, determined that the ultimate in intellectualization of Vitruvian and translated enlightenment concepts of the building process, was to separate the act of conception from production; or segregate design from construction. The Santa Maria Novella, a Basilica in Florence in the $15^{\text {th }}$ century, built in the same city as the Duomo, demon- 
strated a separation of not only ideation and realization, removing the act of design from the act of physical building, but manifested this spatially with a false façade and more traditional structure in tow - a literal disjuncture between aesthetics and structure, defining the functional roles of both the building and its development participants. (Fig. 2)

From the fall of the Romans to Alberti, little to no record of technical drawings existed outside of Vitruvius' writings. Ideas and results were one in the same. However, for Alberti, ideas were demonstrated as an intention of the designer in two-dimensional orthographic projections of what was otherwise a three-dimensional space of material of construction. His creation of architectural drawing technologies, in the example of the drawing machine, encouraged designers to be removed from means and methods - the beginning to a separation of disciplines in the building industry. Designers to this day are removed from making, and constructors separated from ideation.

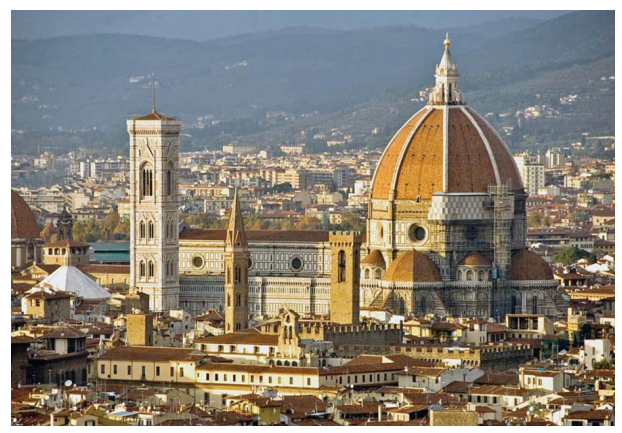

Figure 1: Florence Cathedral, Brunelleschi, $15^{\text {th }} \mathrm{C}$.

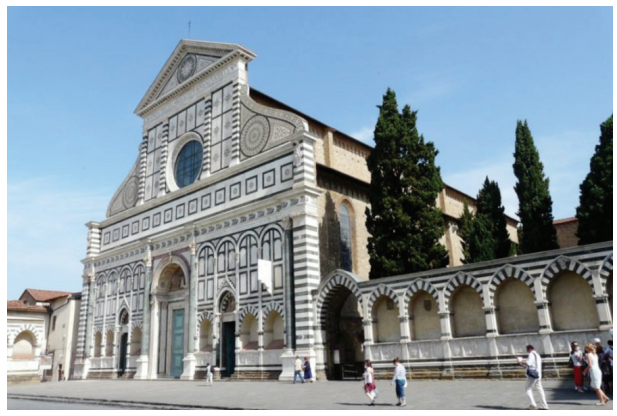

Figure 2: Santa Maria Nouvella, Alberti, $15^{\text {th }} \mathrm{C}$.
Today the roles and responsibilities of designers and constructors are further segregated. Cultural divides are reinforced through contractual means that must be strictly adhered to and abided with the breach of which clearly delineated. This fundamental condition in building culture, the social context just described, passed on since the Renaissance can be called a paradigm, manifest by our cultural values, perspectives, nature of collaborations, practice technologies and buildings.

\section{WICKED PRACTICES}

Design and planning researchers Horst Rittel and Melvin Webber described design and production practices and their attenuate negative performances as a "Wicked Problem" - wicked meaning wickedly nasty, difficult, hard to understand and/or solve. ${ }^{2}$ Jeff Conklin states that "Wicked Problems" require being "highly informed and intelligent just to understand them". ${ }^{3}$ Wicked problems, or for our purposes wicked practices, are fragmented by the two major forces - the social and the technical including but not limited to the disintegrating characteristics to follow:

- The solution to wicked practices depends on how the performance is framed and the definition depends on the solution. Whereas construction is not generally considered rocket science, it likely should be, because it is one of the most complex social and technical undertakings in human existence - it is unique every time, the site is different every time and the labor is mutable and inconsistent. ${ }^{4}$

- $\quad$ Stakeholders in practice have radically different world-views and different frames for understanding practice. Design and production separation traditions are the default socio-technical context for practice from the Renaissance forward. This context is further frustrated by the fact that traditional contracts motivate constructors to focus on getting the contract 
rather than bettering the process and product- lessening the value to the owner.

- The constraints of practice are subject to and the resources needed to perform change over time. The only thing more complex than the uniqueness of building process is the mutability of prices changing constantly during the building of a facility. Construction process truly is a series of moving targets.

- $\quad$ Building performances are never concluded definitively. Building solutions are not optimal - as a scientist might find an ideal solution to a problem, rather each building practice represents compromise, negotiation and one of many appropriate solutions.

- Time is running out and schedule is critically important.

- Those seeking to integrate socio-technical performances are also causing their fragmentation. We truly are our own worst enemy in construction.

- $\quad$ Finally, there is no central authority. This is sometimes called the problem of asymmetrical information, meaning a lack of knowledge transfer mechanisms between stakeholders in both directions of design and construction. Since owners and designers know relatively little about production and economics, means and methods are easily hidden, and a lack of transparency results in an uncompetitive market, further reducing innovation in construction.

\section{Problematics and Statistics}

Recent research statistically illustrates the market and environmental impacts of socio-technical fragmented wicked practices:

Paul Teicholz from Stanford demonstrates based on U.S. Bureau of Labor and Statistics data that from 1964 - 2004 all other non-farm industries increased in productivity, that is they produced more output with the amount of labor input while the construction industry fell by $10 \%{ }^{5}$ Construction is the worst economically performing industry second only to the airlines. ${ }^{6}$ We are less productive at building buildings today than we were in 1964 . The recession of 2008 does not make this condition easier bringing unemployment levels in the U.S. construction sector in recent reports to near $18 \%$. That is double the unemployment rate of the nation as a whole. ${ }^{7}$

Environmental scientists relate that the greatest contributor to global warming is green house gas emissions via carbon-dioxide pollutants. The Department of Energy reports that buildings use nearly $70 \%$ of the electricity in the U.S. equating to $50 \%$ carbon emissions due to the reliance on coal fire power plants, and thereby being the single largest industry sector contribution to climate change. ${ }^{8} \mathrm{~A}$ reduction in energy use in buildings stands to save a significant amount of environmental degradation and climate change impact in the near and long term.

\section{INTEGRATION AND ENTANGLEMENT}

Culturally engrained from Cartesian scientific method and dualism, the separation ontology of the social and technical found in social sciences, organizations, and most especially in the building industry leads to a lack of knowledge communication and therefore digression in construction innovation. Duality in the $21^{\text {st }}$ century is necessarily being abandoned in favor of a relational ontology - enmeshed socio-technical factors. In applied terms of building, this can be called an entanglement of practice. ${ }^{9} \mathrm{Mi}$ chel Callon and Bruno Latour's Actor Network Theory is an example of the entangled practice. Here human (social) and non-human (technology) actors impact one another in a network. ${ }^{10}$ But the focus is not on the actors, rather their connections; or as Karen Barad states, "the act of doing is the theme of study, the physics of 
practice". ${ }^{11}$ From this performative perspective, technologies have no inherent properties, boundaries or meaning, but together with social aspects of building practice perform to produce a different outcome than would otherwise be experienced - one that gives more agency to the actors or building participants, architects, engineers, constructors and owners.

Dorthy Leondard states that innovation occurs at the boundaries between disciplines. ${ }^{12}$ Therefore, important to performative practices is defining and recognizing the building disciplines' knowledge boundaries. More important however, is to find ways to communicate across knowledge boundaries thereby entangling and integrating practice. This entanglement of socio-technical performances is the work of semiotics, or the linking of communicative connections between actors - human and nonhuman. In seimotics human actors integrate a framework, or a network of connections of human and non-human across industry and disciplinary boundaries in order to communicate knowledge. ${ }^{13}$ Once social and technical factors are entangled and unified they can be leveraged to their full capacity to realize the end goal - knowledge communication.

\section{CURRENT TECHNOLOGIES}

The practice technologies of the 21st century including $B I M, I P D$, and $\angle E E D$ are intended to foster and frame these communication and knowledge transfers leading to innovation and agency of players - integrating and flattening the design and construction - social and technical aspects of building practices. Each of these technologies will hereafter be discussed in light of socio-technical parameters.

Building information modeling (BIM) is an information rich solids three-dimensional modeling concept that encourages building virtually before building physically. The ultimate implementation of BIM would be an open-source platform where building projects are digitally conceived, programmed, designed, visualized, subjected to various simulations, reviewed for code compliance and constructed directly from the digital model which then would serve the owner in operating the facility. The BIM model (or models) would be a series of interconnected data structures and be directly accessed by all project participants real time. The realization of this goal would change how projects are created at every stage, yielding new models of design and construction practice. While technically feasible, this ideal faces many serious social obstacles in reality. ${ }^{14}$

In a 2010 issue of AEC Bytes, Randy Deutsch reminded his readers of GSA's Charles Hardy's statement, "BIM is about $10 \%$ technology and $90 \%$ sociology". Deutsch went on to assert "ninety percent of what has been written, analyzed and studied about BIM so far is the technology. While the $10 \%$ technology works itself out," he continued, "we would as an industry do well to turn our attention toward the $90 \%$ that we share, the sociology of Integrated Design." ${ }^{15}$

Integrated Project Delivery (IPD) works to define a relational ontology and a new set of socio-technical relationships in a project. ${ }^{16}$ IPD is generally supported by a multi-party relational agreement. The first multi-party relational agreements in the construction sector were developed for and by the UK offshore oil and gas industry in the 1980s. There are now a number of different relational agreements available internationally including the Integrated Form of Agreement for Lean Project Delivery developed in 2005 ${ }^{17}$, the popular AIA C191-2009 Standard Form Multi-Party Agreement for IPD in $2008^{18}$, ConsensusDOCS300 by the AGC in $2007^{19}$, and similar agreements in the UK and Australia commercial building industry over the past two decades.

Relational contracts create a collaborative system with shared responsibility for managing and sharing risk and incentives tied to the amount of value generated by the end product. The American Institute of Architects (AIA) has recently published an online interactive case 
study matrix that places IPD projects with their parameters and performance results, authored by Renee Cheng at the University of Minnesota and AIA Minnesota. ${ }^{20}$ In addition, Jonathan Cohen produced a document published by the California AIA and AIA National that likewise reported on case study examples of IPD completed projects. ${ }^{21}$

A clear conclusion from this research is that IPD never takes on the exact form from project to project due to the uniqueness of the team, context and conditions. However, similar themes continue to emerge from project stakeholders including the following social functions: early involvement of key participants, shared risk and reward, multi-party contract, collaborative decision making and control, liability waivers among key participants, and jointly developed and validated performance goals. In addition, stakeholders report the following desirable characteristics on the project case studies: mutual respect and trust among actors, reaching for collaborative innovation, and open communication.

Since its inception in 1993, the U.S. Green Building Council (USGBC) has led in providing green building standards and is undisputedly the industry leader for green building assessment methods. Initially developed for new construction in commercial buildings, LEED has expanded to existing buildings, schools, healthcare, commercial interiors, neighborhood development, and most recently to LEED for Homes in 2008. The rating system is voluntary, which is adopted in the design and construction of buildings.

Recent studies from the New Building Institute illustrates that LEED certified buildings are not performing as designed. ${ }^{22}$ To achieve technically high performing buildings that consume less water, material and energy, social integration of the design and construction process is necessary. The Department of Energy, National Renewable Energy Laboratory documented six high performing buildings in 2006 . The clear factors that contributed to the projects' successes were not technologies by way of renewable energy or high resistance value exterior walls as one might first consider. Although these tactics may have been deployed as a result, an integrated process that unified the technical and social aspects of practice to achieve high performance goals was most effective. ${ }^{23}$

\section{SOCIO-TECHNICAL DEMOCRACY}

The technologies of BIM, IPD and LEED in order to be performative in practice must be considered socially while they are employed technically. Perhaps the most important lesson of the emergence of these technologies is the fact that they will be replaced by further refined socio-technical models in the future. As Mark Dodgson writes:

There is no one correct solution or answer for every alliance; each one must be designed and managed in its own unique fashion to fit its own circumstances.... The innovation process is iterative, and its management should be integrated throughout its various stages. Strategic management cohesion is necessary through the process. ${ }^{24}$

Technologies are challenged when humanity find aspects of their existence not served by the technical environment. Although one could delineate technology from social life, today in entangled practices, one can no longer ignore the politics of technology. Andrew Feenberg writes, "only a democratically constituted alliance of actors, embracing those affected, can resist harmful technologies." ${ }^{25}$ Technological innovation, of the democratic kind, does not lead to an impoverishment, deterioration, or amputation of society. On the contrary, it is entirely oriented toward its enrichment thereby opening a new perspective - this is no longer a matter of opposing a modernization believed to be synonymous with failure, or of threats to eliminate or risks to control. Rather, as Callon suggests, it is by going deeper into modernization - that is, by acknowledging the creative and mobilizing power of technologies when 
they are shaped socially and democratically - that the difficulties encountered and the injustices of modern life economically, politically, humanitarian, so rightly denounced can be overcome. $^{26}$

Therefore, technology should be designed with the concerned groups represented and having participated fully in its development. We may question, has this been done with BIM, IPD and LEED? Will this be the case with future technologies of practice? As technology is social and technical, we, society, the creators of technology are ultimately the ones to decide. Technical democracy is the only solution that respects the true essence of technology and society binary. Or, again as Callon states, "No good democracy without technical democracy and conversely no good technique without democracy."27

This requires a socio-technical activism on the part of practitioners and academics to proactively and democratically shape practice technologies to the greatest degree of agency and performance possible, and not be relegated to corporate or bureaucratic notions of practice.

\section{CONCLUSION}

What is the next step? The following are suggestions for future research on integrated practices:

The socio-technical variables that fragment design and construction cannot be treated simply as an operational problem (i.e. IPD). Transformations in the building industry requires both an understanding of physics of project delivery, and the social, cultural, behavioral context in which building practice unfolds. This includes the political and market structures in relation to project delivery, project type, project site and project budget dynamics. ${ }^{28}$ What is needed is a transformation from polemical prose and traditional criticism theory in design scholarship to a robust social / organizational science and theory of practice research agenda, innovating and clarifying performance and knowledge transfer in design and construction.
This research and development should be on the techniques of practice such as integrated delivery methods, and sustainability metrics for increased predictability and control in design and construction that can provide project teams with a wider choice of tactical methods for accomplishing the strategies set forth by integrated practices. Further, we need to develop methods to evaluate the capability of these practice technologies to support integrated process and environmental design goals from conception to completion.

BIM has many technical obstacles that must be overcome through research and development to have greater impact as a tool for integrated delivery including adoption, interoperability, ownership and storage of models, personnel training and overhead, and document signing with the caveat - all to the empowerment and agency of stakeholders. Socio-technical research is needed to improve flow in production phases of project delivery visa via digital material denominations.

These topics for research in integrated design and construction demonstrate the continuing need for an increasingly broad and systemic view of the industry on behalf of all stakeholders including owners, architects, engineers, constructors, specialists and users. Without these different perspectives, it is difficult to identify the structural and social barriers to process innovations in performative practice and to understand the socio-technical opportunities and challenges that make a meaningful difference, more agency for all, in the field and in the design studio. ${ }^{29}$

A final thought on the socio-technical in contemporary building:

Perhaps the crucible of transformation to integrated practice will not depend on the design or construction professional with knowledge of the technical, but rely on the human resource department with knowledge of the social. 


\section{ENDNOTES}

1. Marx, K. Capital: A Critique of Political Economy, Volume I Book One: The Process of Production of Capital. First published 1867 (German), English edition first published in 1887, Samuel Moore and Edward Aveling (Transl.) (Moscow, USSR: Progress Publishers) : 125

2. Rittel, H. \& Webber, M. "Dilemas in General Theory of Planning". Policy Sciences 4. (Scotland: Elsevier Scientific Publishing Company 1973): 155-169.

3. Conklin, J. Dialogue Mapping: Building Shared Understanding of Wicked Problems. (John Wiley \& Sons, Inc. 2005).

4. Ballard, G. \& Howell, G. "What Kind of Production is Construction?" (Proceedings IGLC - 8, 1998).

5. Teicholz, P. "Labor Productivity Declines in the Construction Industry: Causes and Remedies". AECbytes. Viewpoint \#4, April 14, 2004. Accessed 06.28.11.

6. "The Partnering Process - Its Benefits, Implementation and Measurement". Construction Industry Institute (CII) (Clemson University Research Report 10211) 1996.

7. "Construction Unemployment Drops to Less Than $18 \%$ in April". Engineering News-Record 05.11.2011. http:// enr.construction.com. Access 06.28.11.

8. 2009 U.S. DOE Buildings Energy Data book.

9. Pickering, A. The Mangle of Practice: Time, Agency and Science. (Chicago, IL: University of Chicago Press, 1995).

10. Callon, M. and Latour, B. Science in Action: How to Follow Scientists and Engineers Through Society (Cambrdige, MA: Harvard University Press, 1988).

11. Barad, K. 2003. "Posthumanist performativity: toward an understanding of how matter comes to matter". (Signs, vol. 28, no. 3) : 801-31

12. Leonard-Barton, D. "Well Springs of Knowledge: Building and Sustaining the Sources of Innovation". (Boston: Harvard Business School Press, 1995).

13. Carlile, P. "Transferring, Translating, and Transforming: An Integrative Framework for Managing Knowledge Across Boundaries". Organization Science_Vol. 15, No. 5. September-October 2004 (INFORMS) : 555-568 \& Orlikowski, W. "The Sociomaterility of Organisational Life: considering technology in management research". Cambridge Journal of Economics. (Oxford Journals 2010, 34) : 125-141.

14. Smith, R. Prefab Architecture: a guide to modular design and construction. (Hoboken: John Wiley and Sons, Inc, 2010) : 72-73.

15. Deutsch, R. "Notes on the Synthesis of BIM". AECbytes Viewpoint \#51 (April 7, 2010) http://www.aecbytes. com/viewpoint/2010/issue_51.html. Accessed 06.28.11.

16. Cohen, J. Integrated Project Delivery: A Guide, Version 1 IDP Guide 2007. AIA National/AIA California. Available gratius download at the AIA's website: www.aia. org. Accessed December 2010.

17. http://www.mhalaw.com/mha/newsroom/articles/ ABA_IntegratedAgmt.pdf

18. http://www.aia.org/aiaucmp/groups/aia/documents/ pdf/aiab081563.pdf - list of distributors from: http:// www.aia.org/groups/aia/documents/pdf/aias076340. pdf

19. http://consensusdocs.org/catalog/300-series/
20. Cheng, R. and AIA Minnesota. IPD Case Studies. (AIA Center for Integrated Practice. February 8, 2011.) http://network.aia.org/AIA/CenterforIntegratedPractice Home/Default.aspx Accessed 06.28.11.

21. Cohen, J. Integrated Project Delivery: Case Studies. (The American Institute of Architects, California Council in partnership with AIA, 2010). http://www.aia.org/ about/initiatives/AIAB082049 Accessed April 2010.

22. "Energy Performance of LEED for New Construction Buildings". (New Buildings Institute, March 2008). http://www.newbuildings.org/energy-performanceleed-new-construction-buildings Accessed 06.28.11.

23. Torcellini, P., Pless, S., Deru, M., and Griffith, B. "Lessons Learned from Case Studies of Six High-Performance Buildings." U.S. Department of Energy, National Renewable Energy Laboratory. Report No. NREL/TP550-37542. June 2006.

24. Dodgson, M. Technological Collaboration in Industry: Strategy, Policy and Internationalization in Innovation. (London: Routledge, 1993) : 152.

25. Feenberg, A. Between Reason and Experience: essays in Technology and Modernity. (Cambride: MIT Press, 2010) : 28

26. Callon, M. "Afterword" in Between Reason and Experience: essays in Technology and Modernity. (Cambride: MIT Press, 2010) : 225

27. Ibid.

28. Smith, R., Mossman, A., \& Emmitt, S. "Editorial: Lean and Integrated Project Delivery Special Issue". Lean Construction Journal, 2011 www.leanconstructionjournal.org : 13.

29. Ibid, p.14. 